European Journal of Enterprise Technologies. 3, 2 (105), 37-47. DOI: https://doi.org/10.15587/1729-4061.2020.203301.

6. Pievtsov H., Turinskyi O., Zhyvotovskyi R., Sova O., Zvieriev O., Lanetskii B., and Shyshatskyi A. (2020). Development of an advanced method of finding solutions for neuro-fuzzy expert systems of analysis of the radioelectronic situation. EUREKA: Physics and Engineering, (4), 78-89. https://doi.org/10.21303/2461-4262.2020.001353

DOI https://doi.org/10.30525/978-9934-26-046-9-15

\title{
ЗАСТОСУВАННЯ ДЗЗ/ГІС-ТЕХНОЛОГІЙ ДЛЯ МОНІТОРИНГУ МІСЦЬ ЗАХОРОНЕННЯ ВІДХОДІВ
}

\author{
Шевчук О. В. \\ аспірант \\ Інститут телекомунікацій і глобального інформаційного простору \\ Національної академії наук Украӥни \\ м. Київ, Украӥна \\ Азімов О. T. \\ доктор геологічних наук, старший науковий співробітник, \\ провідний науковий співробітник \\ Науковий центр аерокосмічних досліджень Землі \\ Інституту геологічних наук Національної академії наук України \\ м. Київ, Україна \\ У наш час у переважній більшості країн світу, зокрема, й в Україні, \\ проблема забруднення навколишнього природного середовища різно- \\ манітними відходами стоїть дуже гостро, а отже $є$ актуальною. \\ В останні роки спостерігається значне зростання обсягів накопичення \\ побутових відходів різних типів (наприклад, твердих) на сміттєзвали- \\ щах та полігонах. \\ Полігони захоронення та сміттєзвалища твердих побутових від- \\ ходів (ТПВ) належать до екологічно небезпечних об'єктів. Їх експлуа- \\ тація призводить до забруднення практично всіх компонентів навко- \\ лишнього середовища - грунтів, поверхневих і підземних вод, атмо- \\ сферного повітря, рослинності тощо.
}


Використання космічних знімків і цифрових карт місцевості дозволяє проаналізувати просторове розміщення полігонів побутових та промислових відходів, причому не тільки стосовно населених пунктів, але й враховуючи також особливості геосистем у зонах розташування об'єктів захоронення. Ці особливості визначають ландшафтні умови, в яких відбувається накопичення відходів. Космічні знімки також дають змогу вивчати процеси, що відбуваються у геосистемах умови міграції забруднюючих речовин, які утворюються у процесі експлуатації звалищ, а також ті умови, що необхідні для підтримання штатного технологічного режиму складування і переробки відходів [1, c. 77-79; 3, c. 70; 4, с. 4-5; 5, с. 7-8].

Основна мета публікації співзвучна з однією з важливих проблем у галузі поводження з ТПВ. Ця проблема полягає у формуванні загальних принципів створення й у визначенні основних складових інформаційної системи геомоніторингу районів впливу полігонів захоронення ТПВ, як частини інформаційно-аналітичної системи аналізу ризику виникнення надзвичайних ситуацій техногенного та природного характеру, спрямованої для забезпечення сталого регіонального розвитку України $[1$, с. $71 ; 4$, с. $2 ; 5$, с. 5]. Отож, частиною проблеми є дослідження можливостей використання геоінформаційних технологій та даних дистанційного зондування Землі (ДЗ3) для аналізу розміщення полігонів захоронення побутових та промислових відходів із врахуванням геодинамічних особливостей територій їх розташування. У цьому аспекті було поставлено основне завдання досліджень: оцінювання зміни у часі геометричних параметрів і стану карт одного з узятих для прикладу сміттєзвалищ ТПВ у Рівненської області України - Здолбунівського.

3 метою моніторингової оцінки просторово-часових змін Здолбунівського звалища застосовувалися методи комп'ютеризованого дешифрування даних ДЗ3 різних років і технології геоінформаційних систем (ГІС).

Методика дистанційного моніторингу полігонів ТПВ включає підбір космічних знімків із необхідними показниками просторового розрізнення та періодичності зйомок заданих ділянок місцевості, подальше їхне тематичне дешифрування й інтерпретацію [1, с. 74; 2, c. $30 ; 3$, с. $63-64 ; 4$, c. $3 ; 5$, c. 6-7].

Дослідження сміттєзвалища доцільно проводити у два етапи: виділення об'єкта на дистанційному зображенні та розпізнавання його класу. На етапі його виділення, як апріорна інформація, що просторо- 
во поєднана із зображенням на космічному знімку, використовуються карти місцевості. У результаті формується вектор ознак об'єкта для кожного пікселя зображення. На етапі розпізнавання класу того чи іншого об'єкта передусім формується вектор ознак для кожного 3 наявних на місцевості класів об'єктів та безпосередньо виконується розпізнавання (класифікація) на зображенні кожного з досліджуваних об'єктів [2, с. 30-32; 3, с. 65].

Вивчення динаміки зміни площі Здолбунівського сміттєзвалища за період 2003-2019 рр. виконано за спектрометричними характеристиками i текстурою земних утворень, які отримані за наявними космічними знімками (рис. 1). У результаті виділено карти звалища, що експлуатувалися у різний час, виявлені зміни рослинного покриву на прилеглих до нього ділянках, також вдалося дешифрувати шляхи під'їзду до об'єкта захоронення відходів та в його межах, що були задіяні у різні роки. На космічному знімку за серпень 2019 р. добре розрізняється поточний стан звалища, насамперед його внутрішня «структура»: відпрацьовані ділянки, що покриті шаром грунту; ділянки, де в даний час складуються відходи; різноманітні під’їзні шляхи, що використовувалися у різний період функціонування об'єкта захоронення відходів, тощо.

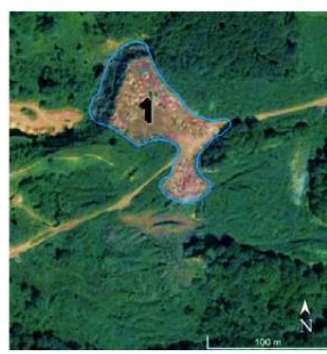

Серпень 2003 р.

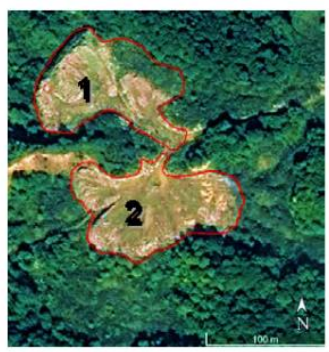

Вересень 2014 p.

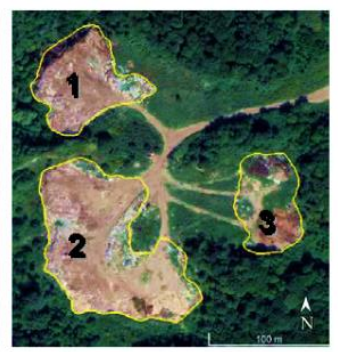

Серпень 2019 р.

\section{Рис. 1. Контури черг Здолбунівського сміттєзвалища ТПВ,} що виділені на космічних знімках різних років

У процесі дешифрування було виявлено поступове збільшення площі сміттєзвалища ТПВ поблизу м. Здолбунів. Аналіз космічних знімків території показав, що порівняно з 2003 р. станом на 2019 р. його загальна площа збільшилася приблизно у 3,13 раза (рис. 1,2, табл. 1). Так, у 2003 р. на звалищі експлуатувалася лише одна карта

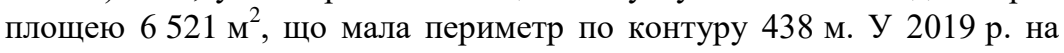
64 
сміттєзвалищі вже задіяно три карти загальною площею $20438 \mathrm{~m}^{2} 3$ сумарним периметром по їхніх контурах 1083 м. Тобто периметр карт звалища збільшився більш ніж у 2,47 раза.

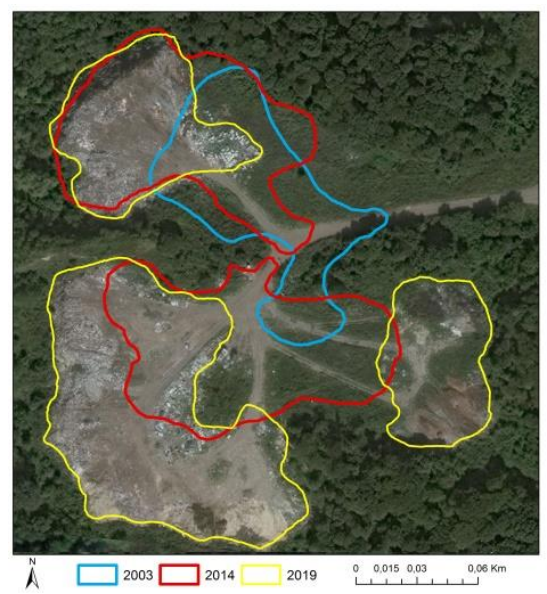

Рис. 2. Картосхема зміни геометричних параметрів черг Здолбунівського сміттезвалища ТПВ за даними космічних знімків різних років (вектори меж черг звалища станом на 2003, 2014 та 2019 рр. показано різними кольорами).

Таблиця 1

Оцінка динаміки зміни геометричних параметрів черг Здолбунівського сміттезвалища ТПВ за даними космічних знімків різних років

\begin{tabular}{|c|c|c|c|c|}
\hline $\begin{array}{c}\text { Дата } \\
\text { космічної } \\
\text { зйомки, } \\
\text { місяць/рік }\end{array}$ & $\begin{array}{c}\text { Кількість окремих } \\
\text { частин (черг, } \\
\text { карт) сміттєзва- } \\
\text { лища, одиниць }\end{array}$ & $\begin{array}{c}\text { Площа } \\
\text { черги, } \\
\text { м }^{2}\end{array}$ & $\begin{array}{c}\text { Загальна площа } \\
\text { сміттєзвалища, } \\
\text { м² }^{2}\end{array}$ & $\begin{array}{c}\text { Периметр } \\
\text { черги, } \\
\text { м }\end{array}$ \\
\hline $08 / 2003$ & 1 & 6521 & 6521 & 438 \\
\hline $09 / 2014$ & 1 & 8103 & \multirow{2}{*}{16460} & 432 \\
\hline & 2 & 8357 & & 438 \\
\hline \multirow[t]{3}{*}{$08 / 2019$} & 1 & 5179 & \multirow{3}{*}{20438} & 319 \\
\hline & 2 & 11497 & & 514 \\
\hline & 3 & 3762 & & 250 \\
\hline
\end{tabular}

Висновок. Отже, на прикладі Здолбунівського сміттєзвалища ТПВ (Рівненська область, Україна) показано інформативність 
дешифрування його карт і прилеглих ділянок за спектрометричними характеристиками і текстурою земних покривів (прямими дешифрувальними ознаками), які отримані за космічними знімками різних років. Продемонстровано також інформативність вивчення динаміки зміни геометричних параметрів (площа, периметр) звалища, зміни його внутрішньої «структури», функціональні зміни в оточуючих його кварталах лісових масивів.

\section{Література:}

1. Азімов О.Т., Шевчук О.В., Азімова К.О. Геоінформаційні системи в дослідженнях чинників забруднення довкілля територій сміттєзвалищ: стан та перспективи. Геоінформатика. 2020. № 2 (74). C. 69-88. URL: http://www.geology.com.ua/ (дата звернення: 05.03.2020).

2. Кохан С.С., Москаленко А.А. Оцінка можливості ідентифікації звалищ за багатоспектральними космічними знімками. Вiсн. геодезії та картографіï. 2009. № 6 (63). С. 29-34.

3. Шевякіна Н.А., Трофимчук О.М., Красовський Г.Я., Клименко B.I. Методи і моделі космічного моніторингу зон впливу полігонів твердих побутових відходів на довкілля. Косм. наука і технол. 2019. T. 25, № 1 (116). C. 62-72. URL: https://doi.org/10.15407/knit2019.01 (дата звернення: 05.03.2020).

4. Azimov O.T., Shevchuk O.V. Geoinformation systems in monitoring studies of environmental pollution factors in the areas of municipal solid waste landfills. Theoretical and Applied Aspects: Proc. 19th EAGE Int. Conf. on Geoinformatics (11-14 May 2020, Kyiv, Ukraine). Kyiv, 2020. P. 1-7. URL: https://doi.org/10.3997/2214-4609.2020geo111 (дата звернення: 05.03.2020).

5. Azimov O.T., Shevchuk O.V., Azimova K.O., Dorofey Ye.M., Tomchenko O.V. Integration of GIS and RSE aiming to the effective monitoring of the surroundings of landfills. Укр. журн. дистанційного зондування Землі. 2020. Вип. 27. С. 4-12. URL: https://doi.org/ 10.36023/ujrs.2020.27.183 (дата звернення: 05.03.2020). 